\title{
Impact of the World-Wide Web on today's society: an economic perspective
}

\author{
Dewald Scholtz \\ Post Graduate Diploma in Information Management \\ Rand Afrikaans University \\ scholtzd@aforbes.co.za
}

\section{Contents}

Introduction

Problem statement

Research Method

What is the Internet?

A definition of economics

How does the Internet impact economics?

What is the effect of the Internet on the world economy?

Conclusion

$\underline{\text { References }}$

\section{Introduction}

Samuelson (2000) writes: 'This spirit inevitably invests the Internet with transcendent significance. Steve Case of America Online already calls the new century 'the Internet Century' and some authorities whisper that the Internet rivals the importance of Gutenberg's invention of the printing press in the 15th century.'

Krugman (2000) is of the opinion that technology plays a big role in the economy of the world by greasing the wheels of production.

The richest man on earth is Bill Gates who built his wealth on operating systems and is currently desperately attempting to re-align his company to take advantage of the possibilities of the Internet. This is attracting the displeasure of the anti-trust (competition board) legislators in America.

Steve Case of AOL concluded the largest business deal ever by buying Time Warner and creating the largest Internet company (Nocera 2000).

In every issue (for the last 2 years) of Fortune magazine and most issues of Newsweek and The Economist, the importance of the Internet for the world economy is highlighted (as established from Fortune, Newsweek and The Economist archives). 
From the above paragraphs it is obvious that the Internet is having and will have a significant impact on the economy of the world at present and in the foreseeable future.

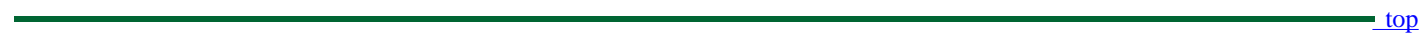

\section{Problem statement}

How does the Internet impact on today's society with a specific focus on economics and finance?

To answer the research problem, certain sub-problems will be used to highlight the different aspects of the research question:

- What is the Internet?

- How does the Internet impact economics?

- What is the effect of the Internet on the world economy?

\section{Research method}

A literature review will be utilised to answer the research problem.

\section{What is the Internet?}

Business Day (1999) defines the Internet as the global computer network.

Apteker (1997) states: 'The Internet is a computer network of networks and is functionally rich in applications.'

From the above it is clear that the Internet is a grid of computers that are linked with each other. How they are linked (the infrastructure) does not form part of this report. The links between computers allow communication to take place and to shorten the time in which information can be sent, received and retrieved.

\section{A definition of economics}

Mohr and Fourie (1995) take the definitions of various authors to conclude that economics is the science which studies human behaviour as a relationship between ends and scarce means, which have alternative uses. The central elements of economics are therefore scarcity and choice. One has to choose how scarce resources will be used to fulfil certain needs. The basic fact of economic life is that there are simply not enough goods and services to satisfy everyone's wants.

Three types of resources (factors of production) are available to satisfy the wants of individuals, namely natural resources (e.g. land or minerals), human resources (e.g. labour) and man-made resources (e.g. machines). 
The Internet impacts economics with regard to its central elements: scarcity and choice. It also impacts on the factors of production.

\section{Scarcity}

The scarcity of resources is reduced through the optimal allocation of the resources. Scarcity may be the result of the resource not being available in one place but may be abundant elsewhere. Scarcity may also occur because the resource is in short supply everywhere and even better allocation may not make a difference as regards to its availability.

\section{Factors of production}

\section{Natural resources}

A simple example regarding the optimal allocation of scarce resources may be a shortage of pork bellies in Arkansas, United States of America, while there may be an abundance available in Zimbabwe. By means of the Internet it is possible for two traders to become aware of each other on the Internet where the African advertised and the American found the producer.

Although this example is simplistic, it must be remembered that information flow was severely limited by a number of factors in the past. In the 14th century (before the printing press) the vast majority of people did not even know what the Bible said apart from what priests told them. Information was limited and utilized by those in power to obtain more power.

Even 20 years back the use of knowledge as power was frequently used in South Africa by the government and its propaganda machine. It was quite difficult to obtain accurate information on the situation in South Africa as opposed to the situation in the rest of the world because of the manipulation of information.

Today it is possible to access information on a virtually endless number of topics on the Internet. This fact frustrates the rulers of autocratic countries such as Iraq and China because it is so difficult to control the access of every single person to the Internet.

In the same way that information on democracy has become freely available, so has information on scarce resources. Instead of breaking up rock in Holland to create sand, it is now possible to import it from where it is abundant - Namibia! (and at half the price).

Even where natural resources are genuinely scarce (not just through allocation), it is possible to reduce the scarcity through the exchange of information on the Internet. An example of this would be the scarcity of gold that can be alleviated through the use of a better mining method discovered in the Ural mountains of Kazakhstan and published on the Internet for discussion.

\section{Human resources}

The Internet has a massive impact on the use of people to accomplish tasks. It is not necessary to require people to immigrate to your country to employ them for their skills (scarce resource). It is now possible to have people all over the world working for your company by linking them with the Internet.

Three interesting examples illustrate this point: 
The accounting function of Swiss Air is done in Delhi, India and not in Sweden. The Swedish population is highly skilled but also very expensive. The accounting information is captured in India and collated and sent to Sweden on a daily basis.

Anderson Consulting is a world wide management consultancy that uses a novel technique to solve client problems. Any issue that arises anywhere in the world can be put onto the company's dedicated Internet. Someone on the other side of the world may know the solution and will respond. Amazingly, it is now possible to work on a client's problem 24 hours a day.

A final interesting example is that many lines of code for software packages are written in Mumbai and Bangalore, India, on behalf of software makers all over the world. The product may be made in America - but the code was written in India!

\section{Man-made resources}

It is possible to reduce the scarcity of man-made resources through better communication and information exchange, similar to the discussion under natural resources.

An interesting point does, however, come to mind: e-money. In an attempt to attract people to their Web pages, some companies are rewarding the visitors by allocating so- called green beans. These green beans can be used to purchase merchandise or services from participating sites. A whole new virtual man-made currency is being created. In effect, individuals are paid for browsing and loyalty to certain sites. The scare commodity of 'real' money is therefore made less scarce as individuals can earn on the Internet.

\section{Choice}

The word 'choice' refers to the decision that people must make on how to utilize their scarce resources (time, money and skills) to fulfil their needs and wants. By spending their scarce resources they can obtain other scarce resources available in the marketplace. Choice has to do with how people allocate their resources.

\section{Factors of production}

\section{Natural resources}

The consumer must choose what natural resources are needed to fulfil needs and wants. In the everyday world, shoppers would, for instance, go from one shop to the next to find the best price for bread, milk or perhaps gold bullion (arbitrage specialists in the commodities markets would attempt to find the best price for gold).

The choice is however increased substantially through the medium of the Internet. Instead of going to a shop to purchase groceries, it is now possible to go to an online retailer who would take the order, charge your credit card (or green beans) and deliver the goods to your residence.

Speciality retailers are also able to offer exotic products on the Internet that are not stocked by the local deli. One can for instance order pure (scarce) Java coffee from Burundi. The scarce resource is therefore obtained from a new source and causing the local store to be unable to sell the chicory mixture available on its shelves.

\section{Human resources}

Choice in this regard refers to the human resources to be used and the choice one has to make 
between different individuals. An example in this case would be the same as the previous Swiss Air example. It is possible to obtain the necessary skills and time from individuals from all over the world with minimal interruption to their lives.

Another fascinating example of the choice of human resources exists on the Internet in terms of the recruitment agencies that have sprung up. It is now possible to recruit people from all over the world and to contact individuals in most locations, whereas in the past the recruiter would quite simply not have been aware of these people.

The recruitment process has in fact gone one step further in that job seekers can publish their curriculum vitae on the recruitment site and let companies bid on the individual. This may sound suspiciously like slavery, but what the job seeker is in effect doing is selling his/her skills as a commodity on the open market. This approaches the Keynsian ideal of a totally open and free market where supply and demand will always reach perfect equilibrium because all information is available to all participants at the same time.

\section{Man-made resources}

In the same way that buyers can make decisions on obtaining natural resources, they have a far wider choice in the purchasing of man-made goods. For example, it is possible to purchase a computer from Dell in America that is cheap and of very high quality, thereby forcing local importers, manufacturers and distributors to cut their margins.

\section{What is the effect of the Internet on the world economy?}

From the foregoing it is clear that the Internet is having an impact on the scarcity and choice regarding production. This clearly has far-reaching consequences for the world economy. The American economy has reached and passed the longest growth period in history owing to the effect of information technology and the Internet (as stated by Alan Greenspan, Governor of the American Federal Reserve).

Many economies are built on the power of the Internet. Singapore is an excellent example of this and Hong Kong is doing its best to emulate the brilliant infrastructure available in Singapore.

A new economic paradigm has evolved through the use of the Internet. The classical economic model of paying for a product or service has been turned on its head. Computers are given away for free so as to entice more people to look at certain sites. These sites then command higher advertising fees. Start-up companies who list on the NASDAQ are often valued at several billion dollars without showing a cent of profit! AOL has a larger market capital than General Motors! This means that an intangible service that depends on the loyalty of its customers is worth more than one of the oldest, most successful companies on earth that produces real goods that one can touch and feel!

The stock market has suddenly become very difficult to understand as seemingly insignificant companies command massive amounts of money because of a good idea or business plan but no profit history.

\section{Conclusion}


There can be no doubt that the Internet has changed the economic world as we know it. The generally accepted, 'immutable' rules of supply and demand and risk and return have been shown as too restrictive and inflexible. The Internet is changing the way the world works and the way resources are allocated. Seemingly scarce resources are suddenly more accessible. The choice of consumers and producers has increased exponentially, thereby changing the application of the factors of production.

\section{References}

Apteker, R. 1997. The Internet: recent developments. Presentation to the Wits MBA Class, Johannesburg, 30 April.

Business Day. 1999. Mastering information management. 9 September: 15.

Mohr, P. and Fourie, L. 1995. Economics. Pretoria: J.L.Van Schaik: 8-14.

Fortune. 2000. Archives. [Online]. Available at http://www.fortune.com.

Krugman, P. 2000. The capitalist century. Fortune, March 6: 12-16.

Newsweek. 2000. Archives. [Online]. Available at http://www.newsweek.com.

Nocera, J. 2000. The men who would be king. Fortune, February 14: 24-27.

Samuelson, R.J. 2000. The Internet and Gutenberg. [Online]. Available at

http://www.newsweek.com.

The Economist. 2000. Archives. [Online]. Available at http://www.economist.com.

\section{Disclaimer}

Articles published in SAJIM are the opinions of the authors and do not necessarily reflect the opinion of the Editor, Board, Publisher, Webmaster or the Rand Afrikaans University. The user hereby waives any claim he/she/they may have or acquire against the publisher, its suppliers, licensees and sub licensees and indemnifies all said persons from any claims, lawsuits, proceedings, costs, special, incidental, consequential or indirect damages, including damages for loss of profits, loss of business or downtime arising out of or relating to the user's use of the Website. 
ISSN 1560-683

Published by InterWord Communications for the Centre for Research in Web-based Applications, Rand Afrikaans University 